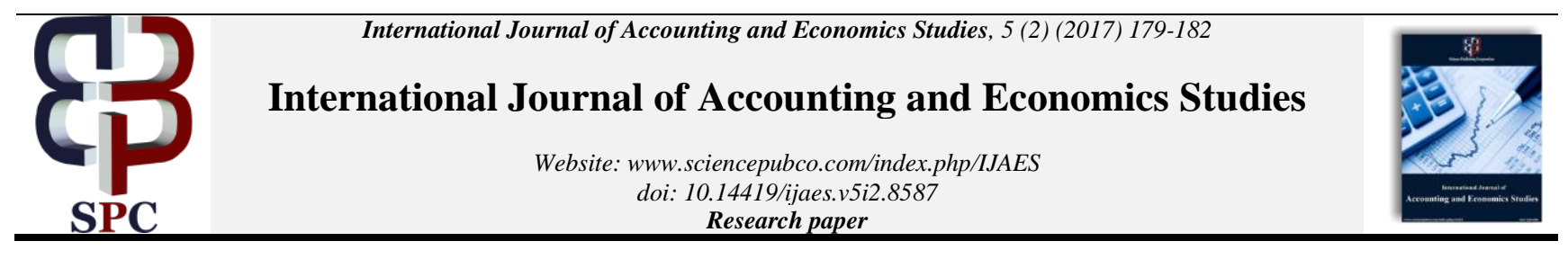

\title{
The theory of measuring human capital history and the present
}

\author{
Valentyn Sobeiko * \\ University of Social Sciences \\ *Corresponding author E-mail: Valyk.007@ gmail.com
}

\begin{abstract}
The manuscript should contain an abstract. The abstract should be self-contained and citation-free and should not exceed 300 words. The abstract should state the purpose, approach, results and conclusions of the paper. The author should assume that the reader has some knowledge of the subject but has not read the paper. Thus, the abstract should be intelligible and complete in it-self (no numerical refer-ences); it should not cite figures, tables, or sections of the paper. The abstract should be written using third person instead of first person.
\end{abstract}

Keywords: Human Capital; Knowledge; Skills; Workers; Education.

\section{Introduction}

For a long time, it was considered that investments for the development and education of workers in the enterprise are unproductive costs. In the economic activities of factories and enterprises, the worker was regarded as a factor of production, performing strictly prescribed functions. Only in the second half of the XX century was the scientific significance of the development of the worker throughout his life scientifically substantiated and presented in the form of a coherent scientific concept. This concept was called "human capital." capital". In the broadest sense, human capital is an intensive factor to economic development and is the core of the knowledge economy and an innovative economy-centered on skills, labour motivation, creativity and employee education.

The first studies devoted to the importance of education and training in the economic development of society were carried out in the XVII century by W. Petty. He assessed the role of man in increasing national wealth higher than the role of means of labour and other factors of production [Ivanov S.V]. Further development of W. Petty's ideas can be found in the works of Adam Smith, who believed that the increase in the productivity of useful labour depends. First of all, on the agility and skill from the worker, his skills and developed abilities, and then on the improvement of the machine and tools with which it works [2]. A. Smith regarded education as the main factor that increased the country's wealth, and advocated its free access for all people. However, the ideas of w. Petty and a. Smith was not appreciated in those days. Their contemporaries perceived value of human labour resource position, but refused to accept it as the main driving factor of production. This in no small measure contributed during the period of the industrial revolution, the possibility of replacing manual labour machines. Marx pointed out that if the nascent stage of capitalism (manufacturing) Simple tools were in addition to the skilled worker, with the development of machine production already people as unproductive labour became an addition to a complex machine [Vesnin V.R] since then, the economic development for a long time was associated only with the invention of new mechanisms, materials, improvement of technologies, rather than intensive factors of development.

At the turn of the XIX and XX centuries in the nature of production, there are major developments: increased its scale, concentration, there were giant's enterprises, tens of thousands of people participated, and in the production of sophisticated technological means. F. Taylor, founder of the Scientific School of management during this time was one of the first who linked the increase of efficiency of production activities within the enterprise with the improvement of condition's employees. According to Taylor, is important for an employee friendly and supportive work atmosphere at the workplace. To do this, open the company endeavoured to provide canteens, evening courses, kindergartens and other objects of social purpose. Views f. Taylor revolutionized the relationship between supervisor and employee. Taylor's system opened and explained the new social role of a leader that should make "the week and careless people in first-class employees" [Vesnin V.R]. However, Taylor's scientific management system from employees and subordinates did not require the manifestation of his own mind, initiatives, suggestions, as this could lead to deviation from the comparison of standards, norms and regulations. That is why training and development works, although it was seen as an intellectual revolution, but was limited to only their skills and skill.

The basis of the origin of the concept of human capital laid supporter's neoclassical direction and Neo-Keynesianism, who believed workers central link in the production activities within the enterprise and their professional development the main condition competitiveness. In the second half of the 1920-lies. Information beliefs spread through the e. Mayo School of human relations. In his opinion, a group of people together, performing common tasks is a complex social system, in which workers have their needs, goals, motivation, and social and psychological factors in work may provide considerably greater impact on productivity. In the 1930-lies. It began to form behavioral D. McGregor and A. 
Maslow, who envisioned the priority disclosure of potential, development of abilities of employees and setting them in the service of the interests of the company.

In the second half of XX century, the importance and effectiveness of development workers reached scientific justification and was framed in the form of the concept of "human capital" $T$. Schulz and G. Becker. The emergence of the concept it was due to another and so that in that time happens- whether indigenous scientific and technical transformation in the life of society, which increased role in intellectual labour rights in its economic activity. In one of his works, in the sacred issue of human capital t., Schultz showed that performance of agrarian technology first just connected with the presence at the farmer the necessary knowledge, skills, information, and their lack of vice versa hampers the efficiency throughout the economy and productivity [Smirnov VT, Soshnikov I.V].

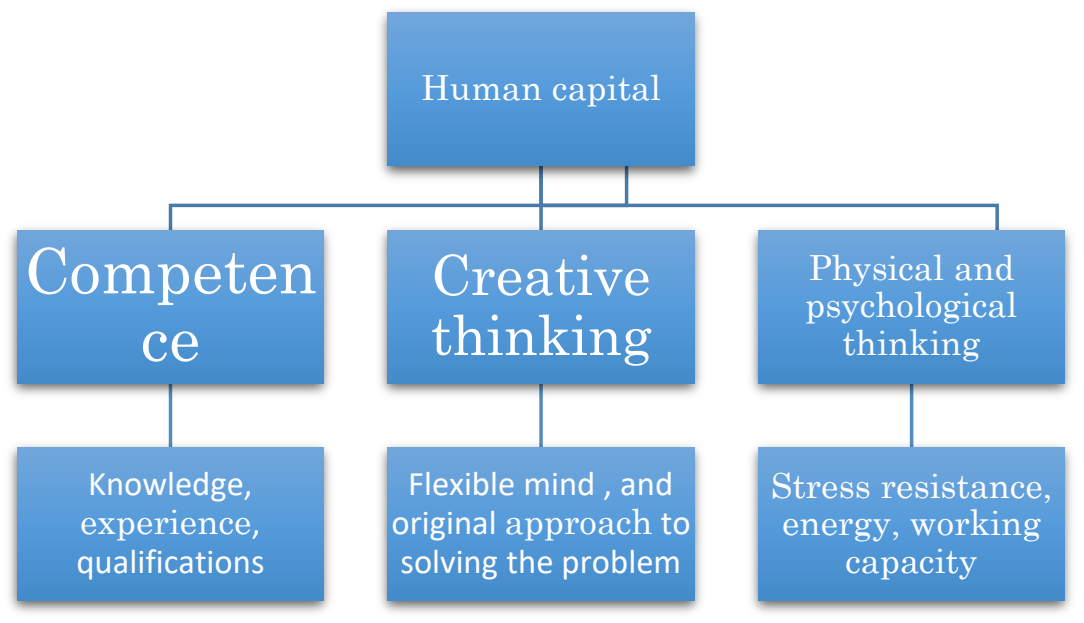

Pic. 1: Structure of Human Capital.

In pic 1 structure of human capital, including competence, creative thinking, physical and psychological health.

Investments increase the value of human capital and bring in more revenue in the future of his medium. The main investments in human capital are costs to education (courses, seminars and trainings), health, medical services, mobility, job search, education of children, the search of information on prices, income, wages [Maksimova V.F]. In studies of the founders of human capital, it has been proven that both the people's Republic of Korea-economic level and at the level of individual employee investments in education, training, health care and other forms of development significantly more profitable than investments in capital. Calculations have been carried out, that the maximum amount of profit from investments in human capital almost 3 times the profit from investments in technology [Kuzmich N.P].

Thus, the role of man in the economic activity within the company gradually changed from. On the one hand, this was due to scientific and technological development, improving the of funds and supplies, on the other hand, is the emergence of new schools and boards, which studied the effect of motivation, creative and intellectual abilities of employees on the performance of enterprises. This continuity has contributed greatly to the scientific establishment of the concept of human capital.

A new stage in the development of a modern economy based on information and innovation further enhances the intellectual requirements and human creativity. There is also a need for nonstandard approaches to be problem-solving that is of interest to the practical application of the concept of human capital management of all levels, from the individual enterprise to the highest echelons of Government.

The concept of human capital will help to ensure economy you are highly qualified workers who give even greater pace of its development and will be essential to the long-term competitiveness of the economy.

\section{Human capital assessment methods}

At the present stage of the development of a market economy, the problem of human capital assessment becomes of particular importance as the basis in the development of business programs for the further development of entrepreneurship and the allocation of labor resources. Economic growth and welfare of individual enterprises have a positive effect of the level of development of the state's economy, which in turn is determined by the level of human development, human capital and the efficiency of its use. For the effective use of human capital, an approach to assessing human capital should be developed as part of a corporate social responsibility strategy.

Paying tribute to the obvious achievements of modern economic science, it should be noted that the issues remain related to human capital, namely: the comparison of income and expenditure on human capital, the assessment of its level of the enterprise to predict the future dynamics of its development, determine its efficiency practical use.

Ensuring the preservation and growth of human capital is a modern strategy for the development of the economy both on the micromezzanine and at the macro level.

\section{Research results}

The problem of human judgment is that traditional accounting only considers the resources that are the property of the enterprise. Due to the fact that the personnel as a special type of resource cannot be neither property nor property, representatives of traditional accounting do not consider it as an object of accounting - an asset (resources controlled by the enterprise as a result of past events, the use of which is expected to result in future economic benefits) [Antonyuk V.P]. At the same time, in the economic literature, due to the lack of clear and unambiguous positions in the understanding about the concept of "human capital" remains the problem of ambiguity of its interpretation.

Since the formation of human capital of the enterprise is based on the personal qualities and characteristics of employees, the main indicators used in the study of human capital of the enterprise may be: the qualification of employees, the advanced level of education, the age structure of staff, the average length of work in the specialty, personnel costs on the basis of this it is possible to generalize the totality of existing approaches to the assessment of human capital of the enterprise. The results obtained are presented in Table 2. 


\begin{tabular}{|c|c|c|c|}
\hline $\begin{array}{l}\text { Methods of } \\
\text { evaluation }\end{array}$ & The essence of the method & Advantages & Disadvantages \\
\hline $\begin{array}{l}\text { The monitor of } \\
\text { intangible as- } \\
\text { sets }\end{array}$ & $\begin{array}{l}\text { The use of a system of strategic indica- } \\
\text { tors that reflects the process of reproduc- } \\
\text { tion and use of human capital }\end{array}$ & $\begin{array}{l}\text { Allows you to get infor- } \\
\text { mation, not about past } \\
\text { achievements of the com- } \\
\text { pany, but about how the } \\
\text { company is developing. }\end{array}$ & $\begin{array}{l}\text { Missing generic parameters in the estimation of human } \\
\text { capital, so management needs to determine a set of indi- } \\
\text { cators which most successfully characterize the activity. }\end{array}$ \\
\hline Cost method & $\begin{array}{l}\text { Includes in the investment in human cap- } \\
\text { ital expenditures of households and soci- } \\
\text { ety on the upbringing of children up to } \\
\text { working age and obtaining a specialty, } \\
\text { retraining and advanced training, health } \\
\text { care, migration, etc. }\end{array}$ & $\begin{array}{l}\text { The possibility of identify- } \\
\text { ing the share of human } \\
\text { capital in national wealth }\end{array}$ & $\begin{array}{l}\text { The disadvantage of this method is that it is impossible } \\
\text { to calculate the net cost of human capital since it does } \\
\text { not provide for the separation of expenditures, which } \\
\text { goes for the reproduction of human capital, to its actual } \\
\text { accumulation. Does not take into account the potential } \\
\text { and existing effect that can be derived from human capi- } \\
\text { tal. }\end{array}$ \\
\hline $\begin{array}{l}\text { The concept of } \\
\text { life cycle and } \\
\text { permanent in- } \\
\text { come }\end{array}$ & $\begin{array}{l}\text { It is based on microeconomic precondi- } \\
\text { tions for planning of consumption and } \\
\text { life-saving savings. That is, future in- } \\
\text { come is planned, which can be obtained } \\
\text { as a result of investments in human capi- } \\
\text { tal. }\end{array}$ & $\begin{array}{l}\text { Savings are seen not only } \\
\text { as postponed consumption, } \\
\text { but also as a process of } \\
\text { forming a portfolio of as- } \\
\text { sets property of the subject. }\end{array}$ & $\begin{array}{l}\text { The complexity in the definition of temporary or occa- } \\
\text { sional income. }\end{array}$ \\
\hline $\begin{array}{l}\text { Natural (tem- } \\
\text { porary) esti- } \\
\text { mates }\end{array}$ & $\begin{array}{l}\text { Anticipate the measurement of human } \\
\text { capital (its educational component) in } \\
\text { human years of study. }\end{array}$ & $\begin{array}{l}\text { Considered one of the most } \\
\text { simple methods. }\end{array}$ & $\begin{array}{l}\text { The accuracy of the method is not always sufficient, } \\
\text { since it is impossible to fully consider the equivalence of } \\
\text { school years at different levels of education, while ob- } \\
\text { taining a General education (school, gymnasium, Ly- } \\
\text { ceum), secondary professional (College) higher (Univer- } \\
\text { sity, Institute), etc. }\end{array}$ \\
\hline
\end{tabular}

Source: Dominos [www1].

For each person, the size of his or her capital determines the necessary expenses, such as the cost of living, the cost of education, the capital of experience, and the workload of one's own. Identifying these inputs and defining the function of capital growth as a result of acquired experience leads to a well-known and well-verified model of human capital presented in many earlier papers [Koziol, 2007, 2010, 2007, 2010; Kurek, 2004; Dobija, 2009, 2010; Renkas 2012a, 2012b, 2013a, 2013b, 2014].].

Human capital is a function of many variables:

$\mathrm{k}$ - Monthly maintenance costs,

$\mathrm{t}$ - time-varying variable,

T-years of work,

p -economic growth potential.

The simplest model of human capital presents the formula:

$\mathrm{H}(\mathrm{k}, \mathrm{t}, \mathrm{T}, \mathrm{p})=\mathrm{K}$

Where: $\mathrm{H}(\mathrm{k}, \mathrm{t}, \mathrm{T}, \mathrm{p})$-value of human capital; K-capitalized maintenance costs using the rate $\mathrm{p}$. A more developed model also includes variables related to professional education and work experience acquired during work. Its form can be described as follows [Cieslak, Dobija, 2007, p.5-24]:

$H(T, p)=(K+E) \cdot[1+Q(T)]$

where: $\mathrm{H}(\mathrm{T}, \mathrm{p})$-value of capital attributed to a person with experience of T years; K-capitalized maintenance costs; E-capitalized education costs; Q (T)-the growth factor of the experience at the end of $\mathrm{T}$ years. The above model can also be presented in an additive form:

$\mathrm{H}(\mathrm{T})=\mathrm{K}+\mathrm{E}+\mathrm{D}(\mathrm{T})$

Where: $\mathrm{D}(\mathrm{T})$ denotes the capital from the professional experience of $\mathrm{T}$ years and $\mathrm{D}(\mathrm{T})=\mathrm{H}(0) \cdot \mathrm{Q}(\mathrm{T})$, where $\mathrm{D}(0)=0$. This model is particularly useful in analysis and the formation of salaries. The human capital model can be supplemented by the coefficient of capital (CR) or the variable Ui, which is used in the human capital model of academic teachers [Goat, 2010]. It determines the size of the capitalized costs for obtaining an this degree (where, ti-means the number of years from obtaining the relevant degree to the moment of measurement). All these models are shown in Table 1.
Table 2: Models of Human Capital Measurement

\begin{tabular}{|c|c|c|}
\hline № & $\begin{array}{l}\text { Models of human capital } \\
\text { measurment }\end{array}$ & $\begin{array}{l}\text { Characteristics of human capi- } \\
\text { tal measurement models }\end{array}$ \\
\hline 1 & $H(T)=K$ & $\begin{array}{l}\text { Human capital of an employee } \\
\text { without education and } \\
\text { professional experience (con- } \\
\text { sists only of from capitalized } \\
\text { maintenance costs) }\end{array}$ \\
\hline 2 & $H(T)=K+E$ & $\begin{array}{l}\text { Human capital of an employee } \\
\text { who has a higher education (ad- } \\
\text { ditional variable appears } \\
\text { capitalized education costs) }\end{array}$ \\
\hline 3 & $H(T)=(K+E) \cdot(1+Q(T)$ & $\begin{array}{l}\text { The human capital of an em- } \\
\text { ployee who has experienced } \\
\text { professional development (cap- } \\
\text { ital growth rate experience de- } \\
\text { pends on the number of years } \\
\text { of they are the most important } \\
\text { first years of work) }\end{array}$ \\
\hline 4 & $H(T)=K+E+D(T)$ & $\begin{array}{l}\text { Addictive form of human capi- } \\
\text { tal model worker's }\end{array}$ \\
\hline 5 & $H(T)=K+E+D(T)+C r$ & $\begin{array}{l}\text { Human capital of an employee } \\
\text { who has capital with creativity }\end{array}$ \\
\hline 6 & $\begin{array}{l}\mathrm{H}(\mathrm{T})=\mathrm{K}+\mathrm{E}+\mathrm{D}(\mathrm{T})+ \\
\mathrm{U} \cdot(1+\mathrm{Q}(\mathrm{t}))\end{array}$ & $\begin{array}{l}\text { The human capital of an aca- } \\
\text { demic worker (where } t_{\mathrm{i}} \text {-the } \\
\text { number of years since of the } \\
\text { scientific degree to the point of } \\
\text { measurement) }\end{array}$ \\
\hline
\end{tabular}

Source: Renkas [2012b].

Using the above models, you can determine the amount of human capital each employee as well, the resulting amount will be the basis for determining owed him a fair wage. It is necessary to emphasize that also important is the level of capitalization, which, studies show [Crane, 2008; Renkas, 2016a, 2016b] is $8 \%$ per year.

\section{Case study}

For example, calculate the cost of human capital for 18 year old student with no work experience which human capital consists only of maintenance costs.

$\mathrm{H}(\mathrm{T})=\mathrm{K}$, where $\mathrm{K}=\mathbf{k} \times \frac{\mathbf{e}^{\mathbf{p} \times \mathbf{t}}-\mathbf{1}}{\mathbf{p}}$

Where:

$\mathrm{k}$ - Onthly maintenance costs,

$\mathrm{t}$ - time-varying variable, 
$\mathrm{p}-$ Economic growth potential,

e - Mathematical constant $(2,72 \ldots)$

Necessary to calculate the data presented below:

$\mathrm{k}=900 \mathrm{zk}$,

$\mathrm{e}=2,72$,

$\mathrm{p}=8 \%=0,08$,

$\mathrm{t}=18$ year.

After adding data to the formula we received the cost of human capital of a model person.

$$
\mathrm{K}=\mathbf{k}(900 \times 12) \times \frac{2,72^{0,08 \times 18}-1}{0,08} \approx 434700
$$

The above cost is the basis for the calculation of fair wage for the worker

\section{Conclusions}

In spite of numerous studies investigating human capital, and the diversity of approaches to its assessment, in practice, during the measurement of this type of capital is a huge number of unresolved issues because some of the human capital assets cannot be directly the assessment. Therefore, it is necessary to use indirect methods of evaluation. This suggests that the counting asset value is a very time-consuming process. However, this is not the only difficulty in the process of evaluating human capital. Much more noise causes the collection, processing and evaluation of the reliability of necessary information at all levels of study (macroeconomic, regional, corporate). All these factors indicate the need for the formation of a universal approach, which would be a superposition of the most productive among them. The choice among these methods makes possible the analysis revealed in the article on the advantages and disadvantages of existing methods.

In their work, the authors suggest to improve the quality of estimation of the human capital approach [Azarova A. A], which gives the possibility of accounting for a broad spectrum analyzed qualitatively varying exposure parameters, which are effective as the basis of the mathematical apparatus of artificial intelligence. This method allows automated dynamically assess the level of human capital experience with the first natural language and with a minimum expenditure of time and financial resources... Theory people capital allows you to set the value of individual people capital which in turn is the basis for calculating fair wages for the worker. This amount of wages the individual retains the employee equity from spraying.

Presented in the article the human capital model is a logical continuation of research within the field of human capital theory. As shown by calculations based on the presented models the cost of human capital is the basis for calculating a fair wages. Such wage guarantees the preservation of human capital from spraying.

\section{References}

[1] Ivanov S.V. Evolution of the research of the economic category "Human capital" // Socio-economic phenomena and processes. 2011. № 7. Page. 55.

[2] Maksimova V.F. Investing in human capital: a tutorial / Moscow. State. University of Economics, Statistics and Informatics. - M., 2004 Page.7-16.

[3] Vesnin V.R. Management: textbook - 4 th ed., Processing and additional. - Moscow: Prospekt, 2012.

[4] Human capital: contents and modes of assessment and promotion: monograph /Smirnov VT, Soshnikov I.V Orel: Orel State Technical University, 2005. Page 513.

[5] Kuzmich N.P. Human capital in the framework of ensuring the competitiveness of the organization in the conditions of the knowledge economy // Theory and practice of social development. 2014. No. 1.

[6] Antonyuk V.P. Formation and use of human capital in Ukraine: socioeconomic assessment and development assurance: monograph / NAS of Ukraine. Institute of Economics of Industrial Design. - Donetsk, 2007. Page 348.
[7] .Azarova A. A. Structural model of intellectualcapital / AA Azarova, A.F Vorobets // The Economics of Economic Analysis. - 2013. - \# 43. . Page 34-44.

[8] Renkas J., 2016a, the Economics of Labor. The theory of fair wages, Scientific works of Wroclaw University of Economics, No. 439, p. 284-301.

[9] Renkas J., 2016b, Wage inequalities and the economic constant of potential growth, Social inequalities and economic growth, 47, pp. 466-480.

[10] Renkas J., 2017a, Capital of Creativity - Measurement and Remuneration, Social Inequality and Economic Growth, No. 50, pp. 413 426.

[11] Renkas J., 2017b, The tandem of "capital-work" as a basis for labor economics, International Journal of Accounting and Economics, Vol. 5, No 1 (2017), pp. 26-32. https://doi.org/10.14419/ijaes.v5i1.7195.

[12] Renkas J., 2012a, Analyzing and Assessment of the Minimum Wage in the Economy of Ukraine on the Basis of Human Capital Theory, In: A. Malina, R. Oczkowska, T. Rojek (ed.), Knowledge - Economy - Society. Dilemmas of the contemporary management, p. 81-86.

[13] Renkas J., 2012b, Empirical Model of Human Capital and Minimum Wage, Social Inequality and Growth, No. 24, pp. 280-291.

[14] Renkas J., 2013a, Human capital and financial reporting, Social inequalities and economic growth, No. 30, pp. 151-161.Renkas J., 2013b, Wage Expectations in Light of Human Capital Measurement Theory, Argumenta Oeconomica Cracoviensia, nr 9, s. 29-42.

[15] Renkas J., 2014, the human capital theory as a basis for the development of financial reporting, W: A. Jaki, B. Mikula (ed.), Knowledge - Economy - Society. Managing organizations: concepts and their applications, s. 343-352.

[16] Cieślak I., Dobija M., 2007, Theoretical basis of human capital measurement, Scientific Writing No. 735, Cracow University of Economics.

[17] Dobija M., 2009, Analysis of convergence of the Polish and Ukrainian economy by labor productivity [in:] Convergence of economic models. Poland and Ukraine, edited by M.G. Woźniak, V.I. Chuzhykov, D.G. Lukianenko, Ed. Foundation of Economic University in Cracow, Cracow.

[18] Dobija M. (ed.), 2010, Theory of Measuring Capital and Profit. Wydawnictwo Uniwersytetu Ekonomiczna w Cracow, Cracow.

[19] Dobija M., 2011, Abstract Nature of Money and the Modern Equation of Exchange, "Modern Economy", Vol. 2, May.

[20] Koziol W., 2007, The use of analytical function of production in the process of wage motivation, Scientific Letters of Cracow University of Economics No. 752, Cracow University of Economics, Cracow.

[21] Koziol W., 2010, forming basic salaries of academic teachers on the basis of measurement of human and intellectual capital [in:] Social inequalities and economic growth. Socio-economic cohesion and modernization of the economy, vol. 16, ed. M.G. Woźniak, Wydawnictwo Uniwersytetu Rzeszowskiego, Rzeszów.

[22] Kurek B., 2004, Culture Creating Function of Accounting [in:] General Accounting Theory. Towards Balancing the Society, M. Dobija, S. Martin, Cracow University of Economics.

[23] Kurek B., 2008, the risk premium estimation on the basis of adjusted ROA [in:] General Accounting Theory. Evolution and Design for Efficiency, ed. I. Górowski, Academic and Professional Press, Warsaw.

[24] www1: https://conferences.vntu.edu.ua/index.php/all-fm/all-fm2017/paper/download/3167/2414 (20.10.2017). 